\title{
Transgender Viewed from the Perspective of Positive Law, Health, and Cultures in Indonesia
}

\author{
Fifik Wiryani $^{{ }^{*}}$, Nurul Ummah ${ }^{2}$, Mokh. Najih ${ }^{3}$, M. Naser ${ }^{4}$, Nur Rohim Yunus ${ }^{5}$
}

1,2,3,4 Faculty of Law, University of Muhammadiyah Malang, Malang, 65144, Indonesia

${ }^{5}$ Faculty of Law, Gosudarstvenny Universitet Upravleniya (GUU) Moscow, Russia

*Corresponding author: fwiryani2016@gmail.com

\begin{tabular}{|c|c|}
\hline Article & Abstract \\
\hline $\begin{array}{l}\text { Article History } \\
\text { Received: Jun 15, 2021; } \\
\text { Reviewed: Jun 15, 2021; } \\
\text { Accepted: Jul 5, 2021; } \\
\text { Published: Jul 8, } 2021\end{array}$ & $\begin{array}{l}\text { Transgenderpeople are seen as an abnormal minority group that bends the accepted } \\
\text { sexual orientation against the cultures in Indonesia. This trend is also believed to } \\
\text { be more prone to diseases. From the perspective of ius constitutum, transgender } \\
\text { people are under different protection as set forth in Article } 1 \text { paragraph (3) of Law } \\
\text { Number } 39 \text { of } 1999 \text { and Article } 28 \text { J of the } 1945 \text { Indonesian Constitution. } \\
\text { However, the human rights governed are restricted to moral and religious, security, } \\
\text { and public order rights. In the view of the positive law, in terms of health, every } \\
\text { individual has his rights to decide how they should live their life, but health is } \\
\text { generally linked to diseases. When it comes to this matter, it can also be deemed } \\
\text { inappropriate or deviant. Transgender people may be deprived of society, and they } \\
\text { may have narrower room for their day-to-day activities such as mingling in religious } \\
\text { activities and society, and even going to the restroom). This sexual tendency could } \\
\text { also cause a serious disease like HIV I AIDS and irritate others due to their } \\
\text { existence around them. In a different view, transgenderpeople are recognized by the } \\
\text { State that attempts to save them from conflicting thoughts of their existence. To } \\
\text { conclude, being transgender is an inner disease existing in an individual. Although } \\
\text { it is seen as normal by transgenderpeople, this reality is still seen as discomfort by } \\
\text { others. }\end{array}$ \\
\hline \multicolumn{2}{|c|}{$\begin{array}{l}\text { (C)2021; This is an Open Access Research distributed under the term of the Creative Commons } \\
\text { Attribution License (https://Creativecommons.org/licences/by/4.0), which permits unrestricted } \\
\text { use, distribution, and reproduction in any medium, provided the original works are appropriately } \\
\text { cited. }\end{array}$} \\
\hline
\end{tabular}

\section{INTRODUCTION}

The existence of Transgender people is no longer seen as a phenomenon since their number keeps growing in society. However, the majority of people still see transgender as an abnormality that infringes on accepted norms living in society (Nurdelia, Jasruddin, \& Daud, 2015). This situation seems to contravene the eastern 
culture in Indonesia (Roby Yansyah, 2018). Other countries such as Germany, India, and others have accepted and legalized the existence of transgender. The State's principle of Bbineka Tunggal Ika (Unity in Diversity) does not represent the presence of transgender, lesbian, gay, and bisexual people. This minority group is left with no recognition from the State. The diversity highlighted in the principle, however, is restricted only to races and tribes, not embracing deviant behavior (Fitri Meliya Sari, 2016).

Being transgender involves a rebel against one's sexuality he/she was born with. Starting with the feeling of discomfort, he/she may feel something is not right with what he/she has been destined to be; a transgender person may even feel he is a woman trapped in a man's figure or vice versa. Transgender people tend to have feelings not representing their real genders (Kurniawati, Lestari, Aziatin, \& Kristanto, 2019).

A source reports that a transgender person may act and feel in a way different from his destined gender, not to mention his interest in the same-sex person. In general, homosexuality cannot only be seen from physical appearance or behavior. When someone admits that he is a homosexual and he displays girly behavior, then he is defined as a transgender person (Akrom, 2017).

The term 'transgender' is often heard to describe a person believing that he was born with the wrong sexuality. Being transgender, however, cannot be specifically defined as something only related to sexual orientation. Some others who believe that they do not have the right gender may also come out as homosexual heterosexual, pansexual, bisexual, or asexual people.

Transgender and transexual are two significantly different terms, where transgender cannot always be defined as transexual. A transexual person not only changes the way he/she behaves not conforming to his/her birth sex, but he/she also changes his/her physical appearance, even his/her genital organ entirely. However, both transexual and transgender people behave not according to their sex birth. a transexual person extremely feels the discomfort within himself/herself regarding his/her birth sex, and this has led to a complete transformation, including the change of the physical features (Nurdelia et al., 2015).

Transexual is seen as a sexual abnormality leading to a conflict between the birth sex one has to bear and his/her mental condition. For example, a man probably physically looks like just most gentlemen with his birth sex, but not the way the man behaves like a female. When this is the case, this man can be identified as an individual with a psychosexual disorder. In several cases, some intend to physically transform their genital organ to conform with their rebelling mind although it is not an appropriate solution or even a therapy, but it is more to the satisfaction a person is willing to take; this is inappropriateness (Yunika Isma Setyaningsih, 2017). 
To give the proper definition of the term transgender, it is necessary to refer to different gender identities according to birth sex or whether a person feels there is different sexual orientation. The transgender is divided into two:

1. Transmen refers to those who were born as boys but identify themselves as men.

2. Transwomen refers to those who were born as boys but they identify themselves as women (Kurniawati et al., 2019).

Transgender is believed to have negative influences on society, and there has been concern that this abnormality affects all generations. Most people believe it is abnormal behavior and its existence brings discomfort to society. Some others even believe that this deviant behavior is contagious and has pushed others away from mingling and interacting with transgender people (Akrom, 2017).

The number of people in search of their identity is growing, believing that they should not have been born with the sex they bear. Some who cannot stand the reality even decide to have surgery to change the genital organ without overthinking about the disdain people may give later in their life (Kurniawati et al., 2019).

Transgender people are often stigmatized since only a few people could take this deviant behavior and most people tend to curse and discriminate against their existence. Article 1 paragraph (3) of Law Number 39 of 1999 concerning Human Rights defines discrimination as an act intended to either directly or indirectly restrict or marginalize a certain group of different religion, race, tribe, ethnicity, social and economic status, language, and politics, and this act could bring further to retainment, reduction, or abolishment of recognition, and the exercise of human rights along with the freedom of life, either for individual or the entire people in aspects like politics, economics, social and cultural aspects, law, and other aspects in people's life.

In a closer look at Law Number 39/1999, freedom to express and to perform in public seems to be restricted since it is seen contravening the religious and moral values, and the security and public order for all people. Article 70 of Law Number $39 / 1999$ requires every person to comply with the limitations set in the provisions of the legislation to ensure recognition and appreciation of the rights and freedom of others and justice in line with moral values, security, and public order in society.

This law also states that rights and freedom as governed in the law is restricted by law to ensure the recognition and appreciation of human rights and the people's basic rights, public order, morality, and certainty of the State (Ramadina, 2017).

Different sexes should not trigger unfair treatment to a certain group of people. Tolerance to any cultural change takes place rapidly amidst the society with people who tolerate good and bad behaviors, but not criminal offenses. Tolerant individuals are likely to welcome new things that are capable of stimulating social change amidst society. 
For example, shemales who are often discriminated against or even prone to scorn or verbal abuse are marginalized. This discrimination will just put the marginalized group in a worse state, confirming that they are the scum of the earth not deserving a place to live in society.

\section{METHOD}

The type of this study is doctrinal research or normative legal research, which is a study that uses data from several regulations (Efendi \& Ibrahim, 2018). Various regulations and cases related to transgender in this study were obtained from various previous studies, this research is not field research, so the author only analyzes existing cases using various theories of law and justice (Peter, 2014). In the legal research method (Irwansyah, 2020), this study compares and analyzes several articles related to transgender in Indonesia, related health perspective, related culture in Indonesia, and some expert opinions obtained from various media, both print and online.

\section{RESULTS AND DISCUSSION}

\section{Transgender People from the Perspective of Ius Constitutum}

In Pure Theory of Law, Hans Kelsen states that the life of civilization is marked by the establishment of an institution that governs social life, and this system gives rise to "public order" (Kelsen, 1949). Living next to one another can also be seen as a biological phenomenon that turns out to be a social phenomenon existing among regulations. All human beings are required to be compliant with the social order that runs its function highlighting particular and shared attitudes, and this social order results in different behavior in each individual. Social order arises from a complex regulatory structure aiming to determine how individuals are supposed to behave in compliance with existing norms (Aulia \& Al-Fatih, 2017).

According to Hans Kelsen, different characteristics come from all different legal structures, and he observed these characteristics in the context of religion and morality. He further states that all the people and legal structures represent a high social concept. Thus, it is necessary to demonstrate social actions as expected by the members of public based on regulations that force, in which these regulations are to be in place to tackle any behavior that contravenes the norm (Akrom, 2017).

In the context of ius constitutum, transgender people have rights to legal protection as governed in the provision of Article 1 paragraph (3) of Law Number 39 of 1999. That is, they call for the State and its people to recognize their existence.

According to ius constitutum, shemales even have their fundamentals and guidelines to determine their rights, as set forth in the 1945 Indonesian Constitution Article J:

1. Every person is required to respect the human rights of others in society and the State. 
2. To exercise rights and freedom, every person must comply with restrictions as set forth in legislation to help ensure the recognition and appreciation of human rights and freedom and to treat people justly according to moral and religious values and social order in a democratic society (Ramadina, 2017).

Indonesia recognizes human rights, and their existence deserves respect and protection from the State. Chapter XA of the 1945 Indonesian Constitution regulates human rights in Indonesia. In a hierarchy, the constitution is the highest law as a reference to make laws under the constitution. In other words, there should not be a single law failing to recognize human rights. Indonesia also accepts UDHR 1948 used as a reference in research concerning international human rights, and this declaration is globally recognized.

The rights to security in Article 28A-28I of the 1945 Indonesian Constitution Amendment 2 are also governed in article 30 of Law Number 39/1999 concerning Human Rights stating "everyone has the right to security and protection against the threat of fear from any act or omission."

Article 35 no. 39/1999 also states "Everyone has the right to live in a peaceful, safe and safe society and nation which fully respects, protects, and executes human rights and obligations as set forth in the provisions in this Law."

Sexual conduct cannot be criminalized based on the perspective of law, as long as this act does not harm others. Criminal law in Indonesia does not recognize the term LGBT since this term is more relevant to the medical or psychological context. This act may be taken as a crime when an offense is committed or there is an indication of causality between sexual misconduct and the crimes caused.

Gay people committing sexual misconduct are governed in criminal law book 2 of Penal Code Chapter XIV concerning Decency Crime in Article 292 stating “Any adult who commits any obscene act with it minor of the same sex whose minority he knows or reasonably should presume, shall be punished by a maximum imprisonment of five years" (Mulyono, 2019).

In terms of sexual orientation, the existence of gender, sexual identity, and the expression of the genders "must" be in the same line. According to the Indonesian Constitution, human rights must conform to religious and moral values, security, and public order. Recalling that Indonesia conforms to the Pancasila (Five Principles) with its first principle mentioning "Belief in the One and Only God", the religion underpins the Constitution to embody the democracy in Indonesian.

Article 70 of Law Number 39/1999 asserts "In executing his rights and obligations, everyone shall observe the limitations set forth in the provisions in this Law, to ensure that the rights and freedoms of others are respected, and in the interests of justice, taking into account the moral, security, and public order considerations of a democratic society." 
Indonesia is a sovereign State with its law, as asserted in Article 1 of Law Number 1/1974 concerning Marriage: "Marriage is the knot between a man and a woman as husband and wife as a basis to build an eternal and happy family in compliance with One and Only God" (Rizka Nor Hashela, 2019).

Marriage is incomparable to LGBT cases, and its legalization will result in issues, including the depletion of birth rate recalling that same-sex marriage can not give any biological offspring.

Married couples as governed in the law refer two both a man and a woman as in Article 14 asserting that "A marriage involves a future wife and husband, a guardian, two witnesses, and a solemnization of matrimony." Article 15 paragraph (1) states "For the merit of the family built following marriage, both man and woman tying the knot must reach a certain age" as set forth in Article 7 of Law Number 1/2014 implying that a man and woman must not be under 19 and 16 years old respectively to get married.

Article 16 paragraph (2) also mentions the form of agreement expressed by future wife in writing, orally or in cues, or even in silence, meaning that there is no rejection of the agreement, and Article 29 paragraph (3) is concerning with the cancellation of marriage due to objection from the woman or her guardian to the future husband. These two articles clearly mention the couple as a man and a woman (Mulyono, 2019).

\section{Transgender from the Perspective of Health Law}

Generally, transgender results from gender dysphoria or gender disorder. Gender dysphoria is a condition where a person experiences uneasy dissatisfaction with the gender identity he/she has had since birth. Most people in this category believe that their gender identity does not correspond to their genital organ as destined, and this is in line with American Psychiatric Association that recognizes the existence of this gender dysphoria (Yunika Isma Setyaningsih, 2017).

It is essential to remember that this case has nothing to do with a mental disorder. However, in several cases of gender dysphoria, people in this category require medical therapy. According to News Medical, a study reports that this condition is not only caused by the failure of correspondence in the brain, but it could also result from biological factors regarding gender identity before a person is born.

According to the book Diagnostic and Statistical Manual of Mental Disorders (DSM-5), it will be inconclusive to decide if a person is developing gender dysphoria unless some symptoms indicate the differences between the gender a person admits it to be true and the gender assumed by another person, and this observation on the symptoms should take at least 6 months. That is, the person may feel that he/she has the wrong gender (Yudhistira Mahabarata, 2019).

World Health Organization (henceforth WHO) once discussed this condition. Back in 2018, WHO issued ICD-11, the new version of a part of International 
Diseases, where WHO reported that transgender was no longer part of mental disorders. Earlier than that, WHO revoked homosexuality from the classification of international diseases in 1990. As previously reported in the Independent, WHO consistently revoked ICD-11 and it will effectuate on 1 January 2022, and, thus, gender identity disorder is changed to "gender inappropriateness" set forth in the sub-chapter concerning sexual conduct, and it is no longer categorized as a mental disorder (Giovani Dio Prasasti, 2019).

In some extreme cases, transgender people go further to genital organ surgery for a complete transformation in search of their identity and recognition from the members of public as that normally given to heterosexuals in general. Gender transformation has been known since the development of the method of Diagnostic and Statistical Manual of Mental Disorder (DSM) although not all have their chance to change their genital organ.

Some experts state that there is a particular observational medical procedure a person has to follow, including hormonal tests, psychological tests, surgery, genetic tests, obstetrics, and gynecology. That is, a person whose genital organ is changed must have followed the range of medical procedures as set by related health practitioners.

In medicine, the DSM method is utilized to track some symptoms such as anxiety about and dissatisfaction with body organs, especially the sex organ, hoping that they could change their sex organ with that of the opposite gender. People with these symptoms also experience ongoing mental disorders for as long as two years and abnormal appearance as an intersex, and they could also develop schizophrenia. J.P. Chaplin in his book Dictionary of Psychology reports that there are several psychotic symptoms indicated by the tendency to self-isolate, emotional and affective disturbance, and negative behavior. Genital organ surgery is categorized as plastic surgery as governed in Law Number 36/2009 concerning Health (Kurniawati et al., 2019).

Transgender people have different sexual orientations from his/her birth sex. Transgender people with this inappropriate sexual orientation are categorized as homosexuals with their gender identity of male, or they can be called transvestite; people in this category tend to wear clothes of the opposite sex and with it, he/she feels satisfied sexually, emotionally, and spiritually.

Sexual orientation falls within the following three categories: heterosexual, homosexual, and bisexual. Of these three categories, homosexual and bisexual are deemed unhealthy, in which people in these two categories wish to build a relationship or closeness with others inappropriately, in comparison to heterosexuals who have the same tendency but appropriately.

In some other sources, it is reported that both homosexuals and bisexuals are more prone to health risks compared to those of the heterosexual category, either physically or mentally. In general, the risk is not only restricted to sexual conduct per 
se, but it is sometimes related to drinking problems and drug abuse. Another study also confirms that this risk could jeopardize the people concerned, or it even causes depression that may lead further to suicide. Needless to say, this tendency is significantly in contrast to those of the heterosexual category.

Bisexual women tend to be prone to drinking problems and smoking, in comparison to heterosexuals. Such attitudes are quite complex since these could expose them to discrimination and violence. To some extent, people with inappropriate sexual orientation could fail to respond to the problems they face, and this situation may seriously bring them closer to stress and depression. When women are in this situation, they tend to smoke, drink alcohol, and use drugs. According to some sources, homosexual and bisexual people are more at risk of HIV (Hasnah, 2019) and some other sexually transmitted diseases such as IMS/PMS (Dany Noviyani, 2017).

These diseases will not transmit to others unless sexual intercourse takes place. The PMS involves gonorrhea, syphilis, herpes, and most often AIDS that could cause the death of the sufferers.

Gonorrhea, caused by Gonococcus, is the most common disease found in PMS. This disease, commonly indicated by pus-filled urine, is transmitted through sexual intercourse. This disease also affects the mucous membrane, eyes, anus, and other organs. Similarly, syphilis, caused by Treponema pallidum, is also transmitted through sexual intercourse, or shared objects such as towels, clothes, and syringes infected by the bacterium. This bacterium tends to attack vital organs such as mucous membrane, anus, mouth, lips, and tongue. AIDS/Acquired Immuno Deficiency Syndrome, the deadliest disease, targets the immunity functioning to protect the human's body against bacteria, viruses, and other diseases (Shinta Anggraeni Kusuma Ningrum, 2016).

\section{Transgender from Cultural Perspective in Indonesia}

Transgender is alarming these days and escalating into a global issue. Movement and community, such as pro-LGBT that supports transgender, seem to be the triggering factor of its spreading. In 1945, this movement was also supported by the Universal Declaration of Human Rights, political bureaucracy reform, and democracy that are commonly mistaken for a liberal process that allows freedom to express in public.

On the other hand, Indonesia is a developing country with its philosophical fundamentals of Pancasila that also mention human rights. Understanding Pancasila requires further details of its improved implementation since more meaningful Pancasila underpins the concept of human rights for the nation in Indonesia.

The LGBT community in Indonesia is the biggest after China, India, Europe, and the US. There are about 26 million Facebook users who decided to come out. According to surveys conducted independently or by foreign survey bodies, the LGBT 
in Indonesia accounts for 3\% of the LGBT population, or 7.5 million out of the total 250 million people. That is, there are 3 LGBT people in every 100 population.

In 2012, the Indonesian Health Ministry estimated that there were 1,095,970 gay people, including those still in the closet, and there were almost $5 \%$ or 66,180 gays with HIV. In 2011, United Nations there would be 3 million people indicated as LGBT and their existence is covered by organizations that allow them to have sex with their counterparts. Recently, the marriage of three gay people in Thailand has shocked the world, and all three declared that they loved each other and expected to move on to a marriage. On Valentine Day, these three men held their wedding on 14 February 2015. The wedding picture of Joke, Belle, and Art in their wedding dress is known by the public online, and it turned out to be a global trending topic (Mona Muliasari, Lacksana, and Nurul Enggar Permana Sari 2018).

In general, prosperous and secular countries will embrace the existence of LGBT/transgender.

On the other hand, the poorer a nation is, the more possible it is for this nation to slow down the growth of the LGBT number. Transgender rights are not apparent in a non-democratic country and a democratic country. Politics and democracy that experience reform in Indonesia have brought about transgender/LGBT-related issues that have been in the spotlight. This situation has encouraged LGBT organizations to grow. In 1968, the term "wadam" (used to refer to Adam Woman) was deemed more acceptable than 'homosexual'.

Governor of Jakarta, Ali Sadikin, facilitated the establishment of Himpunan Wadam Djakarta (HIWAD) for the first time in 1969. In 1980 the term "wadam" changed to "waria" or wanita pria (commonly termed as shemale). This change was triggered by an objection coming from several people to the use of this term since the term "adam", the name of the first Prophet, Adam PBUH, was considered insulting (Roby Yansyah, 2018).

The social identity of shemales is gained from a cultural community, and it requires a certain process of investigation and education at a certain time. The basic elements of the formation of social identity involve ethnicity, race, class, gender, and sexual orientation. Cultural identity is obtained from particular cultures. Cultural identity involves acceptance of tradition and learning process, innate characters/language, religion, and ancestry in a culture of society. An attempt to look beautiful instead of handsome, to have a gentle voice instead of a macho one, and to possess the quality of motherhood instead of fatherhood is intended to get the recognition in society. This is how they build their identity as expected although they may be aware that this trend does not conform to their biological condition. Such an intention indicates there is a desire to change the existing biological characters merely to build a social construction where they could be more recognized and accepted as shemales. 
Identity is defined as one of the central themes amidst globalization. This central theme is understandable since the globalization system these days can have new historical effects that are inevitable amidst the society in general or multi-cultural communities particularly. This tendency will build the feeling that is deeply planted into the society. The identity will be strongly attached to every individual or community, serving as the main element to interact with the rest of the elements in the society.

Gender identity built is linked to several theories such as psychoanalysis, socialization, and cognitive development. For the first time, psychoanalysis theory was introduced by Sigmund Freud (1856-1939), conceptually explaining how a gender identity grows in a person. This theory links behavior to biological factors such as gen, evolution, and anatomy (Nurdelia et al., 2015).

Social-learning theory explains that different gender roles result from what is required by the environment. Gender identity results from a patriarchal society.

Cognitive development theory is more emphasized on the interaction of organism condition, its cognitive development, and information in cultural society. Specific and typical traits in a specific gender represent an interaction between cognitive knowledge and information existing within the culture of society. A social-learning theory is more focused on social components and culture developing from gender behavior, and it is indicated by the different treatment to raise boys and girls upon their birth. A reinforcement model can be performed by parents when raising children by providing them with toys and clothes of particular colors that correspond to their gender, or by giving rewards to them for behaving appropriately. Reinforcement may also involve using typical words to both boys and girls (Nurdelia et al., 2015).

Sudikno Mertokusumo opines that "Society has a religious principle including the message from God to instruct human beings to be pious and obedient. It also demonstrates moral principle and politeness including the norms that shape good, civilized, and moral behavior, and noble characters in human beings" (Kurniawati et al., 2019).

Most transgender activists in Indonesia tend to adapt to pre-existing conditions instead of changing the existing social structure. Culturally, they prefer thinking cleverly to face the existing obstacles to bringing the transformation of the social structure further.

Several factors affect transgender development in Indonesia:

1. Internal Factors

a. Family; this factor includes lack of communication and interaction among family members and the discomfort that triggers an individual to behave inappropriately.

b. Moral Issues; Transgender results from moral deviation in society. Moreover, disappearing social control from society also contributes to the 
situation. Other issues like lack of faith, self-control including desire and lust, and incoming sexual stimuli are believed to also shape an individual into a transgender.

c. Lack of Religiousness; This is considered the major factor linked to the transgender transformation, recalling that transgender is against the concept of the creation of human beings, where Allah SWT only creates a man and woman to live as a respectful couple before God. Lack of awareness of religion serves as an internal factor triggering homosexuality. Religious understanding plays an essential role as the most ideal defense that helps humans to understand what is right and wrong, what is halal and haram.

d. Economic needs. Transgender does not affect people deciding to do some work and it should not serve as the reason why a person does inappropriate work.

2. External Factors:

a. Social network

b. Environment

c. Education

d. International movement

In a different source, Puspitosari (Nurdelia et al., 2015) opines that biological factor contributes to changing a person into transgender, involving sexual hormone and genetic aspect of a person. Other factors are psychological and socio-cultural factors including the environment where a person is raised.

It is common for transgender people to be stigmatized, scorned, and mistreated in society. Some people welcome their existence, but others still see them in disdain and feel irritated by their existence in their society (Kurnia, Widiastuti, Risakotta, \& Syamsiyatun, 2016). Moslem transgender people in Indonesia still face problems where they do not have access to a proper ID, and they do not have their freedom of access to public facilities and professional jobs.

People who welcome the existence of transgender people are often knowledgeable and well educated, and they do not feel reluctant to mingle with the transgender (Damayanti, 2015).

\section{CONCLUSION}

Transgender is deemed abnormal, and it spoils what has been destined by God. The legal protection for transgender people is set forth in Article 30, Article 1 Paragraph (3), and Article 35 of Law Number 39 of 1999. With these articles, they expect that their rights be accepted and recognized in society. However, these human rights are also restricted in Article 70 and 73 of Law Number 39 of 1999. The term transgender also refers to homosexual and bisexual. This sexual orientation is prone to 
sexually transmitted diseases including PMS and HIV-AIDS resulting from their sexual activities and other diseases through syringes, towels, and clothes. The PMS also causes other communicable diseases such as gonorrhea, syphilis, and others that could infect their genital organ. WHO has omitted gender disorder from its list and has replaced it with 'gender inappropriateness', and this change would take effect in 2022. However, it is still believed that this inappropriateness in gender identity is a psychological and medical disorder spreading in the societies in Indonesia. The transgender population accounts for 3\% of the total population in Indonesia, and this number represents the top five globally. In society, transgender is considered deviant sexual behavior that has inappropriate influences on social structure, religion, and norms growing in the society. Moreover, people mostly choose to stay away from transgender people since society still sees transgender contagious. Most people in Indonesia regards transgender/LGBT as she males. Transgender people are facing complex issues dealing with their identity on citizen cards, access to public facilities, and worship activities. Most transgenders are scorned, mocked, and they are vulnerable to violence and discrimination from the members of public.

\section{REFERENCES}

Akrom, C. N. (2017). Transgender Dalam Perspektif Hukum Positif Dan Hukum Islam. Islam Negeri Raden Fatah.

Aulia, F., \& Al-Fatih, S. (2017). Perbandingan Sistem Hukum Common Law, Civil Law dan Islamic Law dalam Perspektif Sejarah dan Karakteristik Berpikir . Legality: Jurnal Ilmiah Hukum, 25(1), 98-113. Retrieved from http://202.52.52.22/index.php/legality/article/view/5993

Damayanti, R. (2015). Pandangan Transgender Terbadap Status Gender dan Persamaan Hak Asasi Manusia di Jakarta, Bogor, Depok dan Tangerang, 2015. Depok.

Dany Noviyani. (2017). Perilaku Seksual Berisiko Infeksi Menular Seksual (Ims) Pada Kelompok Lesbi Di Kota Semarang. Journal of Health Education, 2(2), 122-129. https://doi.org/10.15294/jhe.v2i2.22613

Efendi, J., \& Ibrahim, J. (2018). Metode Penelitian Hukum: Normatif dan Empiris. Depok: Kencana Prenada Media Group.

Fitri Meliya Sari. (2016). Konstruksi Media Terhadap Transgender. Profesional FIS UNIVED, 3(1), 25-34.

Giovani Dio Prasasti. (2019). WHO: Transgender Bukan Lagi Gangguan Mental Health Liputan6.

Hasnah, S. A. (2019). Lesbian, Gay, Biseksual Dan Transgender (Lgbt) Versus

Kesehata: Studi Etnografi. Jurnal Kesehatan, 12(1), 63-72.

https://doi.org/10.24252/kesehatan.v12i1.9219

Irwansyah. (2020). Penelitian Hukum: Pilihan Metode \& Praktik Penulisan Artikel (A. Yunus, Ed.). Yogyakarta: Mirra Buana Media.

Kelsen, H. (1949). General theory of Law and State. [Teoria general del Derecho y del Estado].

Kurnia, R. S., Widiastuti, Risakotta, F. A., \& Syamsiyatun, dan S. (2016). ProblemProblem Minoritas Transgender dalam Kehidupan Sosial Beragama. Jurnal Ilmiab Sosialogi Agama Dan Perubaban Sosial, 10(2), 83-110. 
Kurniawati, N. H., Lestari, E. S., Aziatin, S., \& Kristanto, dan A. (2019).

Transgender dalam Perspektif Hukum Kesehatan. Spektrum Hukum, 16(2), 5265. https://doi.org/10.35973/sh.v16i2.1205

Mona Muliasari, Lacksana, I., \& Dan Nurul Enggar Permana Sari. (2018). MengintegrasikanNilai-NilaiBudayaIndonesiaDanNilai-

NilaiTeoriRealitaDalamMenghadapiKelompokLGBT. 1-7.

Mulyono. (2019). Perkawinan Lesbian, Gay, Biseksual, dan Transgender dalam Perspektif Hukum Islam dan Hukum Positif. Hukum Islam, 4(1), 101-124. https://doi.org/10.29240/jhi.v4i1.789

Nurdelia, Jasruddin, \& Daud, dan J. (2015). Transgender Dalam Persepsi Masyarakat. Jurnal Equilibrium Pendidikan Sosiologi, III(1), 19-28.

Peter Mahmud Marzuki. (2014). Penelitian Hukum. Jakarta: Kencana Prenada Media Group.

Ramadina, Ij. (2017). Tinjauan Yuridis Terbadap Transgender (Transwomen / Waria Analisis Kasus) Di Kota Makasar. UIN Alauddin Makasar.

Rizka Nor Hashela. (2019). Lgbt Dalam Perspektif Hukum Positif Dan Hukum Islam. https://doi.org/10.33059/jhsk.v14i2.907

Roby Yansyah, R. (2018). Globalisasi Lesbian, Gay, Biseksual, Dan Transgender (LGBT) Perspektif HAM dan Agama Dalam Lingkup Hukum Di Indonesia. Jurnal Law Reform, 14(1), 132-146.

Shinta Anggraeni Kusuma Ningrum. (2016). Perilaku Kesebatan di Kalangan Transgender (Studi Deskriptif Kualitatif Tentang Perilaku Detection dan Prevention Dalam Teori Tindakan Sosial di Kota Surabaya). Airlangga.

Yudhistira Mahabarata. (2019). Faktanya Indonesia Memang Bukan Tempat yang Tepat untuk Transgender - Voice of Indonesia.

Yunika Isma Setyaningsih. (2017). Perubahan Kelamin Transseksual Dalam Kaitannya Dengan Sistem Kewarisan Islam (Analisa Terbadap Fatwa MUI Berdasarkan Munas DPP MUI ke II/1980). Islam Negeri Sunan Kalijaga Yogyakarta. 